University of Wollongong

Research Online

Faculty of Law, Humanities and the Arts Papers (Archive)

Faculty of Arts, Social Sciences \& Humanities

$1-1-2013$

Options to protect coastlines and secure maritime jurisdictional claims in the face of global sea level rise

Clive Schofield

University of Wollongong, clives@uow.edu.au

David Freestone

George Washington University Law School

Follow this and additional works at: https://ro.uow.edu.au/lhapapers

Part of the Arts and Humanities Commons, and the Law Commons

Research Online is the open access institutional repository for the University of Wollongong. For further information contact the UOW Library: research-pubs@uow.edu.au 


\title{
Options to protect coastlines and secure maritime jurisdictional claims in the face of global sea level rise
}

\author{
Abstract \\ It is now widely accepted that significant sea level rise is taking place and that this phenomenon is likely \\ to accelerate in the future. This poses potentially disastrous implications for many coastal States, \\ especially those with large and heavily populated low-lying coastal areas, as well as small low-lying island \\ States. In addition to the essentially terrestrial, inward-looking threat posed to low-lying coastal areas and \\ their associated populations from inundation by rising seas, threats also exist looking outward from the \\ land to the ocean spaces adjacent to such threatened territories. In particular, sea level rise has the \\ potential to significantly affect national claims to maritime jurisdiction all the way to the outward extent of \\ maritime zones.

\section{Keywords} \\ claims, face, global, sea, level, rise, coastlines, secure, maritime, options, jurisdictional, protect \\ Disciplines \\ Arts and Humanities | Law

\section{Publication Details} \\ C. Schofield and D. Freestone, 'Options to protect coastlines and secure maritime jurisdictional claims in \\ the face of global sea level rise' in M. B. Gerrard and G. E. Wannier(ed), Threatened Island Nations Legal \\ Implications of Rising Seas and a Changing Climate (2013) 141-165.
}




\section{$\mathrm{CN} \quad 6$ \\ CT Options to Protect Coastlines and Secure Maritime Jurisdictional Claims in the Face of Global Sea Level Rise}

\section{Clive Schofield and David Freestone}

\section{A 1. Introduction}

It is now widely accepted that significant sea level rise is taking place and that this phenomenon is likely to accelerate in the future. This poses potentially disastrous implications for many coastal States, especially those with large and heavily populated low-lying coastal areas, as well as small low-lying island States. In addition to the essentially terrestrial, inward-looking threat posed to low-lying coastal areas and their associated populations from inundation by rising seas, threats also exist looking outward from the land to the ocean spaces adjacent to such threatened territories. In particular, sea level rise has the potential to significantly affect national claims to maritime jurisdiction all the way to the outward extent of maritime zones.

Generally, the coastal baseline from which States' maritime zones are measured is the "normal" low-water line. From this baseline States may measure their territorial sea, contiguous zone, exclusive economic zone, and continental shelf. Consequently, if the low-water mark recedes as a result of inundation and sea level rise, this may affect the measurement of all of a country's maritime zones. Because coastal States' baselines are predominantly based on the "normal" low-water line, if 
those "normal" baselines recede as a consequence of sea level rise, so too will the maritime zones measured from such baselines, leading to the erosion of the coastal State's maritime claims. Further, sea level rise has the potential to inundate small islands and other geographical features that may also be used as critical basepoints in the definition of the limits of claims to maritime jurisdiction. This too may have major impacts on the capacity of an insular feature to generate maritime jurisdictional claims.

This chapter begins by outlining some of the issues and uncertainties associated with the phenomenon of global sea level rise with an emphasis on its uneven impacts both temporally and spatially. Next, the chapter explores potential impacts stemming from sea level rise. It then assesses several responses open to coastal States in the face of rising sea levels. These responses include both the construction of physical defenses, notably in the form of sea defenses, and emerging "soft" engineering strategies and more adaptive planning measures. The final options discussed to preserve maritime jurisdictional claims are legal; among these are options to preserve maritime jurisdictional claims despite the inundation of coasts, including the fixing of normal baselines and/or the maritime jurisdictional limits derived from them. The chapter critically appraises some of these options and proposals open to coastal States seeking to address and adapt to the challenges posed to their maritime jurisdictional rights by sea level rise, drawing on the relevant scholarly literature that has developed on this topic over the past two decades. 


\section{A 2. Sea Level Rise: Complexities and Uncertainties}

Significant evidence exists to support the contention that climate change is already having multiple, sustained, extremely serious, and real impacts on the oceans. Indeed, there now exists broad agreement in the scientific community as to the reality of rising sea levels on a global scale. Chapter 2 discusses in detail the current state of scientific knowledge about the pace and causes of sea level rise and the accompanying uncertainties. As it shows, sea level rise is a phenomenon that exhibits marked spatial and temporal variability. Sea level varies diurnally, under the influence of the tides, but also seasonally, regionally and interannually. ${ }^{1}$ Moreover, the impacts on a particular coastline are substantially dependent on its particular characteristics, such as the morphology of the seabed immediately offshore.

Uncertainties also arise in determining the extent of actual sea level rise against the backdrop of ongoing long-term cyclical changes. However, even relatively modest sea level rise has the potential to have severe consequences and pose major challenges for coastal States.

\section{A 3. Threats Posed by Sea Level Rise}

B 3.1. Threats to Land

The most immediate concern for coastal States is the threat that sea level rise could lead to the inundation of substantial, valuable, and populated parts of their land territory. Such a scenario could in all probability result in the large-scale displacements of coastal-dwelling populations and the loss of associated properties and infrastructure. Even without total or periodic inundation, sea level rise would be 
likely to make such low-lying areas more vulnerable to extreme weather events such as storm surges, thus rendering them less and less habitable. A further consequence could be increasing saltwater intrusion and the loss of valuable habitats such as coastal wetlands, some of which are protected by international treaties. ${ }^{2}$ Alarm bells

over these threats were rung by a number of scholars at least two decades ago. ${ }^{3}$

These threats pose an especially problematic prospect in light of the fact that there is a general migration trend from rural to urban areas and from interior/highland to coastal areas. Indeed, coastal areas represent the most populated parts of the global landmass. One study estimates that sea level rise of one meter would inundate territory presently occupied by around 60 million people. ${ }^{4}$ Significant sea level rise would therefore necessarily pose daunting socioeconomic, environmental, and human security challenges on a global scale.

\section{B 3.2. Threats to Maritime Jurisdiction}

In addition to threats to land territory, sea level rise could potentially result in significant reductions in the spatial extent of national claims to maritime jurisdiction. Changes to coastlines and therefore to baselines leading to the potential submergence of key basepoints from which claims to maritime jurisdiction are measured could have huge and incremental impacts on national claims to maritime jurisdiction. Reductions in the size of zones to which certain coastal States may be entitled are likely to have profound economic as well as jurisdictional consequences, because rights over these maritime spaces dictate exploitation rights over valuable resources that might also therefore be lost. Low-lying island States, such as Kiribati, the 
Maldives, the Marshall Islands, and Tuvalu, which have geographically restricted territory, ${ }^{5}$ appear to be especially vulnerable to these threats. This type of threat is likely to be exacerbated where island groups are particularly dispersed and critical basepoints, on which broad maritime jurisdictional claims depend, come under threat.

However, just as sea level rise is understood to be a spatially and temporally uneven phenomenon, so too are the impacts of sea level rise in light of the variability and complexity of coastlines. A vertical sea level change applied to a relatively steep coastline will have an insignificant impact in terms of the horizontal position of the normal baseline. Where the gradient of the coastline is shallow, however, even a relatively slight vertical change can result in substantial shifts in the position of the baseline horizontally. However, it is by no means the entire normal baseline that contributes to the outer limits of a maritime claim. Thus if the critical controlling basepoints are not affected, then the relevant maritime limits will also not move.

\section{B 3.3. Implications for Islands}

Sea level rise has significant potential consequences for islands and their inhabitants. Most obviously, it could lead to the inundation of parts or even the entirety of the land territory of certain islands, forcing the displacement of significant numbers, or even all, of their inhabitants. Although the total inundation of inhabited islands as a direct result of sea level rise has apparently yet to occur, in certain cases, such as that of the Cateret Islands of Papua New Guinea, the relocation of threatened populations is already planned and ongoing (see later discussion). 
Even if the total inundation of island territory does not take place (at least in the short term), climate-change-related impacts could make it increasingly untenable for island communities to be sustained on certain islands, forcing their populations to leave. ${ }^{6}$ Indeed, even a relatively slight rise in sea level, of a few tens of centimeters, could render certain islands uninhabitable by, for instance, increasing the incidence of severe flooding or curtailing the availability of potable water. ${ }^{7}$ For example, although Fongafale Island, the largest island in Funafuti Atoll, Tuvalu, reaches an elevation of $1.2 \mathrm{~m}$, a sea level rise of $0.6 \mathrm{~m}$ would submerge the island's central depression, which lies between its elevated storm and lagoonal ridges. Many of its population of around 5,000 live there. ${ }^{8}$ Similarly, only one island, Kanton Island, in Kiribati's Phoenix Islands group, is presently inhabited; several other islands in the group supported populations in the past, but no longer can because of a lack of potable water. ${ }^{9}$

Sea level rise also has the potential to threaten the insular status of certain features. For example, an island that is presently always above water level may, as a consequence of sea level rise, disappear during high tide, thus being reduced to the status of a low-tide elevation. (features that are exposed at low tide but are submerged at high tide). Under Article 13 of the LOSC, low-tide elevations may only act as basepoints if they fall wholly or partially within the breadth of the territorial sea measured from the baseline of a State's mainland or island coasts. ${ }^{10}$

Consequently, such features have been termed "parasitic basepoints." ${ }^{11}$ As a result, if sea level rise causes certain features to be reduced to the status of a low-tide 
elevation or to be submerged entirely, the coastal State concerned could lose significant maritime rights. ${ }^{12}$

As a result, it could be Alternatively, sea level rise could lead to the reclassification of a feature from being an, as it were, 'full' island, from which claims to the full range of maritime zones may be made, to one of the categories of insular formation from which only restricted maritime claims can be made. In particular, Article 121(3) of the United Nations Convention on the Law of the Sea (LOSC) of 1982 states that "[r]ocks which cannot sustain human habitation or an economic life of their own" are incapable of generating exclusive economic zone (EEZ) or continental shelf rights. ${ }^{13}$ The significance of such a change of insular status is illustrated by the United Kingdom's reclassification of Rockall from full "island" to "rock" status, resulting in the loss to the United Kingdom of around 60,000 square nautical miles of maritime space previously claimed as part of the United Kingdom's fishery zone. ${ }^{14}$

Whether the threats to the ability of islands to support habitation and thus, ultimately, to the viability of small Island States are solely (or even largely) the consequence of climate change and sea level rise is open to debate. Coral cays, for example, may naturally be subject to evolution and decay over time. ${ }^{15}$ Conversely, it may be that some of these features are capable of natural adaption to sea level rise over time; evidence suggests that coral islands are remarkably robust and enduring features, with the geological record indicating that atolls have survived sea levels a 
half-meter higher than present levels. ${ }^{16}$ Kench indicates that recent evidence from the Maldives suggests that the sea level rose by a half-meter around 2,000-4,000 years ago, after the islands in question were formed, yet the islands developed and remained above sea level. ${ }^{17}$ Similarly, Webb and Kench, in an analysis of twentyseven coral atoll islands in the central Pacific Ocean, found that $86 \%$ of these features had either remained stable or increased in area over a 20- to 60-year timescale despite a reported sea level rise in the central Pacific region. ${ }^{18}$ This phenomenon is discussed further in Chapter 2, but at the least runs counter to widespread perceptions that sea level rise will inevitably lead to the erosion of island shorelines.

A critical issue in this context is the health of coral island ecosystems, as is also highlighted in Chapters 2 and 15. Rising populations, land use changes, pollution, and building work along the coast, including the construction of breakwaters, seawalls, and other sea defenses, can adversely affect the health of coral reefs. In particular such interventions can reduce calcification rates, leading to greater erosion as opposed to coral build-up. Further, the interruption of natural sediment flow regimes can compromise the ability of coral islands to adapt to changing sea levels, undermining the island's natural ability to adapt to sea rise. ${ }^{19}$

\section{B 3.4. Total Inundation of States}

The complete or significant inundation of low-lying States, particularly island States, poses a number of novel legal problems. If the sea level continues to rise steadily, as many scientists predict, this could cause an existential crisis for a number of States. 
Although it does not seem imminent, a number of States have been identified that could be rendered uninhabitable by a one-meter rise in sea level and a subsequent increase in storms, flooding, and the loss of the freshwater lens; that is, the layer of freshwater accumulated from rainfall floating on top of denser saltwater. The question is whether such a State, such as the Maldives, could continue to exist if its land area is completely submerged by the sea or so much of it is under water that it cannot sustain sufficient population to have "an economic life of its own," as required by Article 121(3) of the 1982 LOSC. That said, the lack of specificity in the language of Article 121(3), coupled with the flexible interpretation of these provisions in State practice should be borne in mind.

Such a scenario would raise fundamental questions of continued sovereignty and the ability of such States to continue to function in the international sphere. These issues are discussed by Jenny Grote-Stoutenburg in Chapter 3, and Chapters 8-11 examine the legal status of persons displaced by climate change and the various options for accommodating them in new locations.

It should, however, be borne in mind that the rise in sea level will be a gradual and an episodic process. As long ago as 1989 a Commonwealth Secretariat Expert Group suggested a "variety of ways in which ... it would be possible for many inhabited low lying islands to adapt, albeit with external assistance. ${ }^{20} \mathrm{Webb}$ and Kench's recent study, mentioned earlier, also suggests that sea level rise may lead to unanticipated outcomes, especially in coral island contexts. ${ }^{21}$ Although we should not ignore the problems of complete inundation discussed earlier, planning in the short 
and medium term is important to facilitate effective cooperation needed to combat the less dire short-term effects of sea level rise. Customary international law, as Soons suggests, does provide mechanisms to meet many of the novel situations presented by the effects of sea level rise. ${ }^{22}$

\section{A 4. Response Options}

\section{B 4.1. Planned Retreat and Relocation}

The easiest option, in one sense at least, is to do nothing. Rather than attempting to protect the coast and stabilize its present location, one possibility would be to simply manage the impacts of rising sea levels. Such an approach would allow coastlines to find their own "natural equilibrium," thus avoiding the need to construct costly sea defenses. ${ }^{23}$ The disadvantages of such an essentially passive response, however, are all too obvious. Such an approach would necessarily lead to the inundation of coastal territory, the displacement of populations, the loss of built-up areas and associated infrastructure, and the sacrifice of important coastal habitats such as wetlands. ${ }^{24}$ It is therefore doubtful that such a "do-nothing" policy would prove to be politically acceptable. $^{25}$ Nonetheless, such approaches, that recognize increased dynamism in the coastal zone, could provide for coastal development that is responsive rather than resistant to change. In this context a "planned retreat" would include removing/relocating coastal developments after defined "setbacks" are encroached on through coastal erosion. ${ }^{26}$

For small Island States, the option of simply allowing the landward encroachment of low water lines is even less attractive than for mainland continental 
States, because several small Island States have severely restricted territorial extents. There is little scope for the coastline to retreat before islands may have to be abandoned in their entirety. Indeed, in some States this process is already occurring. In 2005 a decision was made to relocate the 2,600 inhabitants of the Cateret Islands of Papua New Guinea in response to rising sea levels. ${ }^{27}$ Similarly, in 2006, the Indian island of Lohachara, located in the Sundarbans region where the Ganges and Brahmaputra rivers empty into the Bay of Bengal and once the home to 10,000 people, was reportedly evacuated because of the impacts of sea level rise, albeit "as a precaution.",28

\section{B 4.2. Protecting the Coast}

A traditional means of protecting, or at least attempting to protect, a threatened coastline from erosion is implementation of the "bulkhead" policy. ${ }^{29}$ Hard engineering options, such as the construction of sea walls, groins, and wave reduction structures - notably revetments, offshore breakwaters, rock armor, and gabions - are intended to stabilize the position of the coast and protect key infrastructure located in the coastal zones. ${ }^{30}$ It is generally accepted that coastal States can, by implementing such measures, stabilize portions of their baselines and thereby preserve their associated maritime zone entitlements. ${ }^{31}$ While tried and tested, this approach has also repeatedly demonstrated that such construction can result in significant and problematic consequential impacts, including interrupting natural sediments flows and causing unexpected erosion and/or deposition to other parts of the coast. ${ }^{32}$ Indeed, the impacts of such hard defenses are not confined to the coastal zone they 
were designed to protect. Instead, the interruption of natural erosional processes in one area of a coast can affect adjoining coastal areas, depriving them of their sediment supply. In areas where there is already coastal erosion, the bulkhead policy may lead to an acceleration of the natural erosion rate. In one well-documented case on the east coast of England the erosion rate along $15 \mathrm{~km}$ of unprotected coast adjoining a section of seawall increased fourfold over a 50-year period. ${ }^{33}$ Even in areas of coastal deposition, such as estuaries, coastal wetlands, and sand dunes, the deprivation of sediment caused by a bulkhead policy may reduce or prevent accretion that may, in turn, result in increased flood damage to low-lying coastal hinterlands as sea level rise continues. ${ }^{34}$

These types of impacts are especially problematic in the context of coral islands, which depend on uninterrupted sediment flows to sustain the island-building processes that maintain their integrity: "[t]he physical dynamics of sediment supply and transport are critical factors in the context of management of rocky and sedimentary oceanic islands." 35 Consequently, often such approaches have been criticized as large scale, costly, disruptive, and resulting in "unfortunate and sometimes very serious unintended consequences. ${ }^{, 36}$ Instead, an ecosystem-based and sustainable management approach is especially relevant in the management of coral cays and other islands associated with coral reefs. ${ }^{37}$

Unilateral action by one State may have considerable effects on its neighbors. It can be argued that, by analogy with situations that have arisen along shared or transboundary rivers, action by one national authority in building a bulkhead that 
deprives another area in another State of sediment could give rise to liability under international law. ${ }^{38}$ For instance, sediment transport studies within the North Sea suggest that fine-grained sediment, derived from the cliff erosion on the east coast of England, comprises an important source of suspended material in the North Sea that is vital for the accretion of coastal mudflats and marshes bordering Wadden Sea States. ${ }^{39}$ In this instance, a bulkhead policy by one State that seeks to preserve the current coastal morphology may seriously exacerbate the problems faced by its neighbors. In West Africa, Shannon demonstrated that a combination of seawall construction, harbor building, and damming of inland rivers, by depriving the coast of sediment, has led to accelerated erosion in neighboring States. ${ }^{40}$

Boyle points out that the Trail Smelter Arbitration ${ }^{41}$ and the Corfu Channel cases $^{42}$ "have long supported the proposition that no State may cause or permit its territory to be used to inflict serious harm on other States." ${ }^{43}$ It seems clear, therefore, given the current state of awareness of the global nature of the world ecosystem, that a State does not have the right to behave, even in its own territory, in a way that damages its neighbors. Most international environmental lawyers now agree that the behavior of one State that adversely affects shared areas or even damages its own territory in a manner that affects the global ecosystem will give rise to responsibility by that State to others. Of course, a chain of causation must be proved to establish responsibility, and indirect damage may be virtually impossible to prove.

Faced with increasing criticism of hard engineering structures on the coast, engineers and coastal managers have examined alternatives that use the natural 
coastline to absorb wave energy and prevent erosion. For example, in 1992 a UK government report stated,

EXT Increasing realization of the effectiveness [of natural coastal systems] has led engineers to question the value of traditional coastal defences or protective structures. Instead they are examining solutions to coastal problems which seek to control or emulate natural systems rather than to replace them. This has become known as soft engineering - the solution of coastal management problems through environmentally sensitive schemes which involve substantial or total utilization of natural systems as an integral part of the solution. These are more consistent with ecological principles and other conservation interests as well as having greater social acceptability. ${ }^{44}$

Nevertheless, despite the known and notable drawbacks of the bulkhead policy, this hard engineering approach may remain appropriate to protect especially valuable parts of the coast. Such high-value locations may include key coastal locations such as cities (salient, though not necessarily ideal examples include the system of levees at New Orleans and the seawall surrounding Male in the Maldives). ${ }^{45}$

It is also conceivable that States may seek to preserve critical basepoints in this way; Japan's efforts to preserve its southernmost territory, Okinotorishima perhaps represents the most extreme example in this context. Okinotorishima (also known as Douglas Reef) comprises two groups of very small rocks resting on top of a relatively broad coral reef platform. These features are only marginally above the 
high-water mark and are vulnerable to erosion. ${ }^{46}$ Japan takes the view that these features are islands capable of generating EEZ and continental shelf rights. To protect the above-water rocks making up Okinotorishima, in the late 1980s Japan constructed sea defenses, vertically higher than the islets themselves, which form a 360-degree ring around each of the threatened features. It should be noted that Japan's extensive maritime claims from Okinotorishima have been protested by other States. In particular, both China and the Republic of Korea have expressed the view that these features are no more than "rocks" within the meaning of LOSC Article $121(3) .^{47}$

This type of approach, however, is clearly not suited to all coastlines. For example, it has been suggested that the cost of Japan's sea defenses around Okinotorishima exceeded US\$200 million. ${ }^{48}$ Moreover, Lewis has pointed out the problems of building traditional sea defenses for Fanafuti, the main island of Tuvalu on which 2,700 of the country's total population of 8,500 live:

EXT The land form of Fanafuti is so narrow and attenuated that in order to protect its 2.5 square kilometers, 54 kilometers of sea defences would have to be constructed. Moreover, so narrow is the land form for much of its length that sea defences on one side would be protecting the back of sea defences on the other with nothing in between. ${ }^{49}$

In addition, the land behind the defense would have to be raised to prevent flooding from within resulting from the porous character of the coral rock which these features predominantly comprise. The situation is similar in many other coral islands. ${ }^{50}$ 
An analogous approach, and one long practiced by low-lying coastal States such as the Netherlands, has been to undertake reclamation projects as a means to build up or extend coasts. A related response by threatened island States could be the construction of artificial or even floating islands. Indeed, the Maldives is actively pursuing precisely this type of strategy. Its objective is reportedly to construct multiple large artificial islands, elevated to approximately $3 \mathrm{~m}$ above sea level and reinforced with concrete, to provide safe refuges for the country's population. ${ }^{51}$ Although it is acknowledged that, in accordance with the terms of Article 60(8) of the LOSC, artificial islands, together with artificial installations and structures "do not possess the status of islands," "have no territorial sea of their own," and are excluded from affecting maritime boundary delimitation, there appears to be nothing to prevent the extension and, arguably, preservation of a naturally formed feature through reclamation works.

\section{B 4.3. Using Basepoints}

At the core of the legal questions relating to potential impacts of sea level rise on national claims to maritime jurisdiction is Article 5 of the LOSC. This article, which is generally taken to represent customary international law, provides that "the normal base line for measuring the breadth of the territorial sea is the low water line along

the coast as marked on large scale charts officially recognized by the coastal State." ${ }^{, 52}$ Such normal baselines represent the predominant type of baselines worldwide. As discussed earlier and in Chapter 5, it has long been recognized that parts of the coast can be dynamic and can change location and configuration in relatively short periods 
of time. Consequently, as normal baselines change or "ambulate," so too will the maritime jurisdictional limits measured from them. ${ }^{53}$ Although the 1982 Convention does not touch on this issue, it is possible to reach such a view through a "negative implication" of the LOSC (laid out in depth by Rayfuse in Chapter 7). This represents a critical concern in the context of sea level rise.

As Rayfuse further describes, Article 7 of the LOSC permits a coastal State to use straight baselines "in localities where the coastline is deeply indented and cut into, or if there is a fringe of islands along the coast in the immediate vicinity." ${ }^{, 54}$ States that use this system, derived from the judgment of the International Court of Justice in the Anglo-Norwegian Fisheries case, ${ }^{55}$ must comply with other technical conditions ${ }^{56}$ : for example, straight baselines may only be drawn from "appropriate points" - islands and other features that are above water at high tide - and low-tide elevations may only be used as basepoints if "lighthouses or similar installations which are permanently above sea level have been built on them."

However, such straight-line baselines are also potentially threatened by sea level rise, because the basepoints, which "anchor" or tie the defined baselines, may also be inundated and may therefore lose their legal effect. ${ }^{57}$ In such a case, if a lowwater line may be maintained by extensive and, of course, expensive artificial construction, then using similar artificial means to bolster basepoints may also be a legitimate way by which a country can maintain straight baseline points. The artificial maintenance of islets, rocks, and other similar features may prevent them from becoming low-tide elevations. In addition, new artificial installations may be 
built on low-tide elevations to bring them within the terms of Article 7(4). Indeed, coastal States are likely to use the proviso of Article 7 - that the drawing of baselines to and from low-tide elevations is permissible if it "has received general international recognition" - to argue that if features listed on charts subsequently submerge, they can maintain legal status because they have already received the required recognition. $^{58}$

In circumstances specified by Article 7 of the LOSC, coastal States are allowed to use straight baselines joining headlands, islands, rocks, and other features. The disappearance of key geographical features that are used as basepoints, and on which the limits of such claims depend, as a result of sea level rise could have significant impacts on the States. As noted earlier, this threat to the extent of national maritime jurisdictional claims is especially significant for coastal States, such as Bangladesh, that have large stretches of low-lying coasts. Indeed, where a broad coastline regresses rapidly, as in the case of areas of Bangladesh where erosion rates are up to 140 meters a year, ${ }^{59}$ the cumulative effect can be quite substantial. In fact, it was in recognition of Bangladesh's situation that Article 7(2) of the LOSC was drafted. It permits, in restricted circumstances, straight baselines to be maintained notwithstanding the movement of the actual coast:

EXT Where because of the presence of a delta and other natural conditions the coastline is highly unstable, the appropriate points (i.e. for straight baselines) may be selected along the furthest seaward extent of the low-water line and, notwithstanding the subsequent regression [sic] of the low-water 
line, the straight baseline shall remain effective until changed by the coastal State in accordance with this Convention.

Although this provision was drafted for specific circumstances, it has long been recognized that it could be used in response to sea level rise. Most notably, more than twenty years ago some already argued that there was a risk that in the context of sea level rise this limited exception would be used more widely than was contemplated by, or many might regard as legitimate under, the LOSC regime. ${ }^{60}$ The reality of changing baselines in the twenty-first century may, however, prompt attempts to use a much broader application of these provisions.

\section{B 4.4. Islands}

Analogous issues arise in respect of the use of islands as basepoints for the generation of maritime claims. Under Article 121(1), an "island" is "a naturally formed area of land surrounded by water" and is entitled to claim the full suite of maritime zones. ${ }^{61}$ This claim is, however, subject to the important qualification in Article 121(3) that "[r]ocks which cannot sustain human habitation or economic life of their own shall have no exclusive economic zone or continental shelf." ${ }^{\circ 62}$ Although considerable controversy surrounds Article 121(3), ${ }^{63}$ there is at least prima-facie evidence that it has been recognized as customary international law. ${ }^{64}$ Whatever the merits of that debate, sea level rise might well cause low-lying islands to disappear entirely or to lose so much of their area or their freshwater lens as to become uninhabitable and thus be transformed into "rocks," thereby causing them to lose their entitlement to previously established maritime zones. 
Soons' pioneering paper of 1990 explored several options open to a coastal State and islands facing such a situation. ${ }^{65}$ The weight of doctrinal opinion suggests that the artificial enhancement of an existing rock, so as to make it habitable or capable of sustaining an economic life of its own, does not transform it into an island capable of generating EEZ and continental shelf rights. However, the artificial maintenance of an island to prevent it from becoming a "rock" for the purposes of Article 121(3) might, Soons thinks, be permissible. ${ }^{66}$ Certainly, the downgrading of a feature's classification from a small island, or "islet" under the terms of Article 121(1), to a "rock" under Article 121(3) would pose considerable difficulties in determining the status of the maritime zones that it had previously generated, particularly because these maritime zones may have been recognized by other States as being under the sovereignty or jurisdiction of the State to which it belongs. This situation is exacerbated when the maritime claims of States in possession (or, indeed, entirely composed) of low-elevation islands are also under threat from sea level rise; - especially where small, remote, and low-lying islands give rise to significant maritime jurisdictional entitlements. In such cases, Soons suggests that we may see the emergence of a new rule of customary international law that "[c]oastal States are entitled, in the case of landward shifting of the baseline as a result of sea level rise, to maintain the outer limits of the territorial sea and of the EEZ where they were located at a certain moment in accordance with the general rules in force at that time.",67

Moreover, baseline changes could have a bearing on the delimitation of maritime boundaries that are not yet settled. It has long been accepted that, once 
international maritime boundaries are established by treaty, they do not change except through agreement among the parties concerned. Once fixed, therefore, maritime boundaries generally do not shift position if, for example, a basepoint contributing to the construction of the boundary line in question disappears. This is because boundary treaties have a privileged status in the international law of treaties and are not subject to change even in the case of "subsequent fundamental change of circumstances, ${ }^{, 68}$ such as the disappearance of an important basepoint. ${ }^{69}$

\section{B 4.5. Fixing/Declaring Baselines and/or Maritime Limits}

An alternative to physical intervention is for coastal States to try to preserve their baselines and maritime rights through legal means. This strategy would not resolve the issue of inundation of vulnerable low-lying areas. The legal options, however, might well preserve the State's rights over the valuable marine resources that could offer economic support to populations displaced as a result of sea level rise.

Among these options (laid out in detail in Chapter 7), the most promising methods under existing law would be to unilaterally fix maritime jurisdictional claims, decoupling them from ambulatory normal baselines. The justification here comes from Article 5 of the LOSC, which provides that "the normal baseline for measuring the breadth of the territorial sea is the low water line along the coast as marked on large scale charts officially recognized by the coastal state. ${ }^{, 70}$ This language suggests that the key requirement is that the chart be recognized by the coastal States. Consequently, if States do not update their charts to reflect the loss of land territory or basepoints, then the LOSC suggests that the coastal State can be the 
arbiter of its own baselines. Although this could benefit the coastal State, a policy of not updating charts would pose potential dangers to seafarers as official charts become more and more inaccurate over time. A dual charts system of official charts for maritime jurisdictional purposes and navigational charts, however, could resolve this problem.

The more ambitious option would be to negotiate a formal treaty. There is no clear model for creating such a treaty, although options exist, some of which are laid out in Chapter 7, The UN Framework Convention on Climate Change (UNFCCC) is one option. It has provisions for creating new protocols, but has become almost moribund over the last five years, and the 194 parties are currently struggling to negotiate a regime that will come into effect after the Kyoto Protocol commitment period expires in 2012. In 1994, Freestone argued for a sea level rise protocol to be part of the UNFCCC, but such a protocol is unlikely to be a high priority in the current round of negotiations. ${ }^{71}$ Another option, although similarly unlikely, is to amend the 1982 Law of the Sea Convention. In a detailed study, Freestone and Oude Elferink have explored the reasons why States have avoided the complex amendment procedures of the LOSC for both pragmatic and political reasons. ${ }^{72}$ There is also growing momentum, discussed in Chapter 9, for a treaty or other agreement to deal with climate-displaced persons in a way that could also create a solution to some aspects of the maritime zone dilemma. 


\section{A 5. Conclusions}

Sea level rise, as demonstrated in Chapter 2, appears destined to continue and may accelerate, even if the emissions of greenhouse gases are brought under control and their levels ultimately decline. As the global climate system works to bring itself into equilibrium, historical records of times when the global atmosphere had similar levels of greenhouse gases (albeit not from anthropogenic causes) suggest substantially higher sea levels in the decades to come.

The implications of higher sea levels for the territorial integrity of some States are substantial. These implications involve both the inward-looking landward intrusions of water on low-lying areas and also the outward-looking impacts on maritime zones. These threats were well identified by scholars, cited earlier, writing more than two decades ago when the phenomenon of sea level rise was first mooted. The passing of the years has clarified both the reality of this threat and the severity of the long-term trends. It is important, however, to appreciate that, whatever the inevitable very long-term impacts may be in the coming centuries, in the next several decades it will most likely be a gradual and an episodic process. It is also highly likely to be variable both in scale and place - for already it is clear that globally it is not a uniform process - and that both spatial and temporal variability will add considerably to the uncertainties. Although sea level rise clearly has the potential to be cataclysmic, in its early impacts there is some hope that it may be more manageable in certain locations. For example, Webb and Kench's recent study showed that $86 \%$ of Pacific Islands studied are stable or have increased in size over 
the last few decades despite the higher than average reported sea level rise in the central Pacific region. Natural movements of material such as sand and silt that can maintain these processes are, however, impeded by the presence of human structures, and they may not be able to keep up with accelerating sea level rise and with the loss of coral reefs from ocean acidification. Hoping that natural accretion alone will protect the islands and not exploring alternative responses would therefore seem to be foolhardy.

The main response options were also outlined years ago. These include construction of physical defenses and the application of legal options. Some of the options discussed then are repeated here. Physical defenses remain popular and may become more so, yet they are also problematic, not only in terms of cost but also because of their uncertain impacts; more sophisticated engineering solutions are emerging that may possibly mitigate some of the negative externalities of these projects.

From a legal point of view, many have pointed out the problems that sea level rise poses to the complicated maritime zone regime developed by the 1982 Law of the Sea Convention. Because the maritime zones are measured from coastal baselines and basepoints declared or recognized by the coastal State, changes in coastline configuration and land inundation could have serious effects on these zones. Some maritime boundaries, such as those agreed by treaty, are fixed, whereas others may not be. However, it does seem certain that, in the short to medium term at least, States will be reluctant to reduce or abandon any of their maritime claims. Does law 
therefore stand as an obstacle to reaching an accommodation with sea level rise? We think not: the international legal system has a lot more flexibility than it is often credited with. Although formal amendments to the LOSC are highly unlikely, because of the complexity of the procedures that are involved, as Soons pointed out in 1990, international customary law inevitably evolves, and so a solution or a series of solutions seem possible.

The precipitous effects of sea level rise will force States to begin to use some of the opportunities that legal commentators have already highlighted to retain their existing maritime zones or at least to try to minimize their losses. As others have indicated, if the issue becomes pressing, the political organs of the United Nations are likely to become involved. All in all, we remain positive that the gradual and evolutionary nature of sea level rise will facilitate an orderly evolution of the legal regime.

\section{Footnotes}

1 See Climate Change 2007: Working Group I: The Physical Science Basis, Intergovernmental Panel on Climate Change (IPCC), available at http://www.ipcc.ch/publications_and_data/ar4/wg1/en/ch5s5-es.html.

2 David Freestone, International Law and Sea Level Rise, in INTERNATIONAL LAW AND Global Climate Change, 109, 119-22 (Robin R. Churchill \& David Freestone eds., London/Dordrecht: Graham and Trotman/Martinus Nijhoff, 1991); David Freestone \& John Pethick, Sea Level Rise and Maritime Boundaries: international implications of impacts and responses, in INTERNATIONAL BOUNDARIES; FRESH PERSPECTIVES, Vol. 5, 73-90 (Gerald Blake ed., Routledge, 1994). 
${ }^{3}$ D. Freestone, supra note 2; F. Bird \& J.R.V. Prescott, Rising Global Sea Levels and National Maritime Claims, MARINE POLICY REPORTS 177-96 (1989); A.H.A Soons, The Effects of Sea Level Rise on Maritime Limits and Boundaries, NETHERLANDS INT'L L. REV., 37, 207-32 (1990); David D. Caron, When Law makes Climate Change Worse: Rethinking the Law of Baselines in Light of Rising Sea Level, ECOL. L.Q. 17, 621 (1990).

${ }^{4}$ Anil Ananthaswamy, Going, Going..., NEW SCIENTIST, July 4, 2009, at 26, 30.

${ }^{5}$ See The World Factbook, the Maldives, 2010, Central Intelligence Agency (CIA), available at https://www.cia.gov/library/publications/the-world-factbook/geos/mv.html (last visited July 17, 2011). (The land areas of these States are as follows: Kiribati $\left(811 \mathrm{~km}^{2}\right)$, the Maldives $\left(298 \mathrm{~km}^{2}\right)$, the Marshall Islands $\left(181 \mathrm{~km}^{2}\right)$, and Tuvalu $\left(26 \mathrm{~km}^{2}\right)$.

${ }^{6}$ See Ilan Kelman, Island Evacuation, 31 FORCED MigRATION REV. 20 (October 2008). (Kelman identifies five, frequently interconnected, climate-change-related factors affecting island habitability: sea level rise, increased severity and frequency of storms, changes to marine resources, increasing acidity of the oceans, and challenges to freshwater resources). See also Rosemary Rayfuse, W(h)ither Tuvalu? International Law and Disappearing States, in PROCEEDINGS OF THE INTERNATIONAL SYMPOSIUM ON ISLANDS AND OCEANS, 91-93 (Hiroshi Terashima ed., 2009), (Rayfuse has been, correctly, critical of the use of the term "environmental refugees" in this context: "far from protecting the rights of persons displaced due to sea level rise, the use of the pejorative, essentially negative concepts of refugee law serves only to conclusively disempower the persons being displaced").

${ }^{7}$ See Joeli Veitayaki, Pio Manoa, \& Alan Resture, Pacifc Islands and the Problems of Sea Level Rise Due to Climate Change, in Terashima, supra note 6, at 55.

${ }^{8}$ See Hajime Kayanne, Eco-Technological Management of Atoll Islands against Sea Level Rise, in Terashima, supra note 6, at 12, 14-17.

${ }^{9}$ Veitayaki et al., supra note 7, at 55. Note also that the Government of Kiribas has designated the Phoenix Islands a large marine protected area. See http://www.phoenixislands.org/index.php (last visited August 2010).

${ }^{10}$ Clive Schofield \& Chris Carleton, Developments in the Technical Determination of Maritime Space: Charts, Datums, Baselines, Maritime Zones and Limits, 3 I.B.R.U. Maritime Briefing No. 3 at 38 (2001); J.R. Victor Prescott and Clive Schofield, THE 
MARITIME POLITICAL Boundaries OF THE WORLD 107-08 (The Hague, Martinus Nijhoff, 2005).

${ }^{11}$ Clive R. Symmons, Some Problems Relating to the Definition of Insular Formations in International Law: Islands and Low-Tide Elevations, 1 Maritime Briefing No. 5,7 (1995).

${ }^{12}$ Prescott \& Schofield, supra note 12, at 406, 409.

${ }^{13}$ United Nations Convention on the Law of the Sea, December 10, 1982, 1833 U.N.T.S. 397 [hereinafter LOSC].

${ }^{14}$ See Clive Symmons, Ireland and the Rockall dispute: an analysis of recent developments, 6(1) IBRU Boundary AND SECURITy Bulletin, 78 (Spring 1998). See also Clive H. Schofield, Shifting Limits? Sea Level Rise and Options to Secure Maritime Jurisdictional Claims, 4 CARbon \& Climate L. ReV., 405, 406, 409 (2009).

${ }^{15}$ Patrick D. Nunn, OCEANIC IsLANDS 243-49 (1994); David Hancox \& J.R. Victor Prescott, A Geographical Description of the Spratly Islands and an Account of Hydrographic Surveys amongst Those Islands, 1 Maritime Briefing No. 6 (1995); Prescott \& Schofield, supra note 12, at 57.

16 Paul Kench, Understanding Small Island Dynamics: A Basis to Underpin Island Management, in Terashima, supra note 6, at 24-28.

${ }^{17} \mathrm{Id}$.

${ }^{18}$ Of the islands assessed, $43 \%$ remained stable and $43 \%$ increased in area. See Arthur Webb \& Paul Kench, The Dynamic Response of Reef Islands to Sea-Level Rise: Evidence from Multi-Decadal Analysis of Island Change in the Central Pacific, 72 GLOBAL AND PlanetARy CHANGE 3, 234-246 (2010).

${ }^{19}$ See id., at 33, 35; Kench, supra note 16, at 15-19. See also Richard Kenchington, Maintaining Coastal and Lagoonal Ecosystems and Productivity, in Terashima, supra note 6 , at 1-11.

${ }^{20}$ Martin Holdgate, Climate Change, Meeting the Challenge, Report of the Commonwealth Group of Experts, Commonwealth Secretariat, London (1989).

${ }^{21}$ Webb \& Kench, supra note 18, at 234-46.

${ }^{22}$ Soons, supra note 3, at 231.

${ }^{23}$ Freestone, supra note 2, at 119.

${ }^{24}$ Id., at 119-22. 
${ }^{25}$ Id. at 119.

${ }^{26}$ Timothy F. Smith, Stephen Myers, Dana C. Thomsen, \& Johanna Rosier, Integrated Coastal Zone Management and Planning, in MARINE RESOURCES MANAGEMENT (Warwick Gullett, Clive Schofield, \& Joanna Vince eds., 2011) at 115.

${ }^{27}$ See International Organisation of Migration (IOM), Migration, Climate Change and the Environment, IOM Policy Brief - May 2009, available at http://iom.int/jahia/webdav/shared/shared/mainsite/activities/env_degradation/iom_policy brief_may09_en.pdf (last visited August 27, 2010). See also John Stewart, Rising Seas Force Cataret Islanders out of Home, Lateline (ABC television broadcast Feb. 5, 2007), available at http://www.abc.net.au/lateline/content/2006/s1840956.htm. See also Cataret Islanders to be Resettled to Bougainville, SOLOMON TIMES, November 5, 2008, available at http://www.solomontimes.com/news.aspx?nwID=2971. (It was reported that although the first group of islanders were scheduled for relocation in March 2009, many residents had refused to consider leaving the island).

${ }^{28}$ Geoffrey Lean, Disappearing World: Global Warming Claims Tropical Island, THE INDEPENDENT, December 24, 2006, available at http://www.independent.co.uk/environment/climate-change/disappearing-world-globalwarming-claims-tropical-island-429764.html.

${ }^{29}$ Freestone, supra note 2, at 117-19.

${ }^{30}$ Schofield, supra note 11 , at 411.

${ }^{31}$ Soons, supra note 3, at 222.

${ }^{32}$ Freestone \& Pethick, supra note 2, at 73-90.

${ }^{33}$ J. Pethick, Waves of Change: Coastal Response to Sea Level Rise, GEOGRAPHICAL ANALYSIS, 19, 1-4 (1989).

${ }^{34}$ Id.

${ }^{35}$ Kenchington, supra note 19, at 4. See also Kench, supra note 16, at 22-24. See also Schofield, supra note 11, at 411. ("The physical dynamics of sediment supply and transport are critical factors in the context of management of rocky and sedimentary oceanic islands").

${ }^{36}$ Kenchington, supra note 19 , at 4.

${ }^{37}$ Id. 
${ }^{38}$ Freestone \& Pethick, supra note 2, at 73-90.

${ }^{39}$ Id.; I. N. McCave, Mud in the North Sea, in NORTH SEA SCIENCE 75-100 (E.D. Goldberg ed., 1973); D. Eisma, Supply and Deposition of Suspended Matter in the North Sea, 5 Special Publications International Association of Sedimentologists 415-28 (1981); J. Dronkers, J.S.I.J Van Alphen, \& J.C. Borst, Suspended Sediment Transport Processes in the Southern North Sea, in RESIDUAL CURRENTS AND LONGSHORE TRANSPORT (R.T. Cheng ed., 1990).

40 E. H. Shannon, Coastal Erosion and Management along the Coast of Liberia, in Changing Climate And the CoAst, 25-48 (IPCC Working Group III, J. Titus ed., 1990).

${ }^{41}$ The Trail Smelter (U.S. v .Can.), 3 R.I.A.A. 1905 (Tribunal 1938/1941).

${ }^{42}$ The Corfu Channel Case (U.K. v. Alb.), 1949 I.C.J. 4 (April 9).

43 A. Boyle, International Law and the Protection of the Global Atmosphere: Concepts, Categories and Principles, in InTERnational Law and Global Climate Change, (R.R. Churchill \& D. Freestone eds., 1991).

${ }^{44}$ Minister of Agriculture, Fisheries and Food (1992) cited Freestone \& Pethick, supra note 2 , at $84-85$.

${ }^{45}$ See Schofield, supra note 11, at 412.

${ }^{46}$ Song notes that "highest tide" in these two tide features are only 16 and $6 \mathrm{~cm}$ above the surface of the water, respectively. See Yann-huei Song, Okinotorishima: A "Rock” or an "Island"? Recent Maritime Boundary Controversy between Japan and Taiwan/China, in Maritime Boundary Disputes, Settlement Processes, and the LaW of the SeA, 145, 148 (Seoung-Yong Hong \& Jon M. Van Dyke eds, The Hague, Martinus Nijhoff, 2009). See also Joan Brown, Angela Colling, Dave Park, John Phillips, Dave Rotehery, \& John Wright, Case Studies in Oceanography and Marine Affairs 84-85 (Oxford, Pergamon Press, 1991); Prescott \& Schofield, supra note 12, at 84-85.

${ }^{47}$ Permanent Mission of the People's Republic of China to the United Nations, Note verbale to H.E. Mr Ban Ki-Moon, Secretary-General of the United Nations, February 6, 2009, CML/2/2009 (translation), available at http://www.un.org/Depts/los/clcs_new/submissions_files/jpn08/chn_6feb09_e.pdf; Republic of Korea, Permanent Mission to the United Nations, Note verbale to H.E. Mr; 
Ban Ki-Moon, Secretary-General of the United Nations, February 27, 2009, MUN/046/09, available http://www.un.org/Depts/los/clcs_new/submissions_files/submission_jpn.htm.

${ }^{48}$ Brown et al., writing in 1991 , put the estimated cost of the project at $£ 135$ million. Silverstein, quoting Japanese sources, states that the three-year project, starting in 1988, was set to cost US\$240 million. See J Brown, A. Colling, D. Park, J. Phillips, D. Rotehery, \& J. Wright, CASE STUdies In OCEANOGRAPHY AND MARINE AFFAIRS 85 (Oxford: Pergamon Press, 1991). See Andrew L. Silverstein, Okinotorishima: Artificial Preservation of a Speck of Sovereignty, 16 BROOK. J. INT'L L. 409, 410 (1990). Tisdall put the figure at US\$250 million. See Simon Tisdall, China Aims for US to Hit Rock Bottom in Asia, THE GUARDIAN, April 8, 2005, available at http://www.taipeitimes.com/News/editorials/archives/2005/04/08/2003249626.

${ }^{49}$ J. Lewis, Sea Level Rise: Some Implications for Tuvalu, AMBIO 18, 58 (1990).

${ }^{50}$ R.L. McClean, Kiribati and Sea Level Rise, Report on a Field Visit for Commonwealth Expert Group on Climatic Change and Sea Level Rise, Commonwealth Secretariat (1989); A.J. Edwards, The Implications of Sea Level Rise for the Republic of the Maldives, Report to the Commonwealth Secretariat (1989).

${ }^{51}$ Chris Morris, Maldives Rises to Climate Challenge, BBC News OnLINE, March 17, 2009, available at http://news.bbc.co.uk/1/hi/world/south_asia/7946072.stm (last visited October $21,2010)$.

${ }^{52}$ LOSC, supra note 10, at art. 5.

${ }^{53}$ Michael W. Reed, Shore and Sea Boundaries: The Development of International Maritime Boundary Principles through United States Practice 185 (2000); Prescott \& Schofield, supra note 12 , at $100-101$.

${ }^{54}$ LOSC, supra note 10 , at art. 7.

${ }^{55}$ Ango-Norwegian Fisheries (U.K. v. Nor.), Advisory Opinion, 1951 I.C.J. 116 (December $18)$.

${ }^{56}$ LOSC, supra note 10 , generally.

${ }^{57}$ See Schofield, supra note 11, at 413.

${ }^{58}$ Bird \& Prescott, supra note 3, at 177-96. 
${ }^{59}$ D.R. Stoddard \& J.S. Pethick, Environmental Hazard and Coastal Reclamation: Problems and Prospects in Bangladesh, in Understanding THE GREEN REVOLUTION (T. BaylissSmith and E.U. Wanmali, eds., 1984).

${ }^{60}$ Bird \& Prescott, supra note 3, at 177-96.

${ }^{61}$ LOSC, supra note 10, at art. 121(1).

${ }^{62} I d$., at art. 121(3).

${ }^{63}$ B. Kwiatkowska \& A.H.A. Soons, The Entitlement to Maritime Areas of Rocks which Cannot Sustain Human Habitation or Economic Life of Their Own, 21 NETHERLANDS YEARBOOK OF INTERNATIONAL LAW 140-82.

${ }^{64}$ Freestone, supra note 2, at 112.

${ }^{65}$ Soons, supra note 3, at 215-29.

${ }^{66}$ Soons, supra note 3, at 223.

${ }^{67}$ Soons, supra note 3 , at 225.

${ }^{68}$ Vienna Convention on the Law of Treaties, art. 62(2)(a), May 23, 1969, 1155 U.N.T.S. 3318 1. L. M. 679. See also Soons, supra note 3, at 222.

${ }^{69}$ It remains to be seen, however, whether a maritime boundary would survive should baselines recede or disappear to the extent that the maritime zone of one of the coastal States involved no longer extended as far as the agreed maritime boundary line.

${ }^{70}$ LOSC, supra note 10 , at art. 5.

${ }^{71}$ David Freestone, From Copenhagen to Cancun: Train Wreck or Paradigm Shift? 12 ENVTL. L. REV, 87-93 (2010).

${ }^{72}$ David Freestone \& Alex G. Oude Elferink, Flexibility and Innovation in the Law of the Sea: Will the LOS Convention Amendment Procedures Ever Be Used?, in STABILITY AND Change in the Law of the Sea: The Role of the LOS Convention 163-216 (Alex G. Oude Elferink ed. 2005). ("States have systematically avoided the formal Amendment procedure of the Convention despite the time and effort that went into crafting its systems of check and balances. The effort was deemed worthwhile in order to maintain the carefully balanced 'package deal' in which the demands of some groups of states were reflected in the agreement in return for the inclusion of other provisions favoured by other groups. These political compromises could be undermined by selective amendments"). 